\title{
USE OF GEOSTATISTICAL MODELS IN THE SPACE-TEMPORAL EVALUATION OF WATER QUALITY OF AN AMAZONIAN HYDROELECTRIC RESERVOIR
}

\author{
Thiago de Melo e Silva 1, 2, Simone de Fátima Pinheiro Pereira 1, 2, 3,6 (iD, Kellen Heloizy Garcia Freitas \\ 2,4, Pedro Moreira de Sousa Junior 2, 9 \ (DD, Cléber Silva e Silva 2, 5, 6, Davis Castro dos Santos 2, 6, 7 (DD, \\ Ronaldo Magno Rocha1, 2,8, Alan Marcel Fernandes de Souza ${ }^{2}$ (D), Daniel Pinheiro Nogueira ${ }^{2}$
}

\footnotetext{
${ }^{1}$ Chemistry Postgraduate Program, Federal University of Pará, Augusto Correa Street, S/N - Guamá, Belém - PA, Brazil 2 Environmental and Analytical Chemistry Laboratory, Federal University of Pará, Augusto Correa Street, S/N - Guamá, Belém - PA, Brazil

${ }^{3}$ Federal University of Pará, Augusto Correa Street, S/N - Guamá, Belém - PA, Brazil

${ }^{4}$ Federal University of Pará, Cidade Novas 4, Tv.We 26 - Coqueiro, Ananindeua - PA, 67130-660, Brazil

5 Federal Institute of Education, Science and Technology of Pará, Almirante Barroso Street, 1155 - Marco, Belém - PA, Brazil

${ }^{6}$ Postgraduate Program in the National Network for the Teaching of Environmental Sciences, Federal University of Pará. Augusto Correa Street, S/N - Guamá, Belém - PA, Brazil

${ }^{7}$ Federal University of Pará - Altamira Campus. Coronel José Porfírio Street, 2515 - São Sebastiao, Altamira - PA, Brazil ${ }^{8}$ Central Laboratory of the Pará Health Department, Augusto Montenegro Street, 524 - Parque Guajará, Belém - PA, Brazil

${ }^{9}$ Federal Rural University of the Amazon. Barão de Capanema Avenue S/N - Caixa D'Água, Capanema - PA - Brazil.
}

Received 19 September 2021

Accepted 18 October 2021

Published 31 October 2021

CorrespondingAuthor

Pedro Moreira de Sousa Junior, pedro.junior@ufra.edu.br

\section{DOI \\ 10.29121/granthaalayah.v9.i10.2021 .4308}

Funding: This research received no specific grant from any funding agency in the public, commercial, or not-for-profit sectors.

Copyright: (C) 2021 The Author(s). This is an open access article distributed under the terms of the Creative Commons Attribution License, which permits unrestricted use, distribution, and reproduction in any medium, provided the original author and source are credited.

\section{ABSTRACT}

The Tucuruí Hydro-Power Complex reservoir, Pará State, Amazon Region-Brazil, as well as other reservoirs is subject to natural alterations and anthropogenic activities which in turn affect the environmental balance. The aim of this work was to verify if geostatistical models can be used in the spatial-temporal evaluation of water quality in reservoirs. The Surfer 13® software was used to interpolate the spatial distribution of data, in two years of surface water physicochemical parameters were evaluated in sixteen sampling stations. The results of the isotopic maps showed low concentrations of D0 at station C1 in the Intermediate Period 2 (summer-winter), high concentration of COD at station MP in the Intermediate Period 1 (winter-summer) and increased acidity at stations C1 and C2 in summer, suggesting that the relationship between the Tucuruí Hydro-Power Complex and farming activities in the region cause impacts on the aquatic ecosystem along the reservoir.

Keywords: Geostatistical Models, Water Quality, UHE - Tucuruí

\section{INTRODUCTION}

The maintenance of water quality is a determining factor for human health and ecological balance. Such maintenance is influenced by natural activities such as erosive processes, and anthropogenic interference (Lobato et al. (2015); Kazi et al. (2009).

Studies on water quality become valuable in the evaluation of its vulnerability and the level of its exploitation, becoming one of the main topics currently addressed as cited by Di Blasi et al. (2013) and Moreira (2012).

The balance of the hydric ecosystem has an intimate relationship with the natural space-time flow regime, but like most ecosystems, it has undergone 
significant changes in recent years Poff et al. (2007); Döll et al. (2009); Peñas et al. (2016). According to Lobato et al. (2015) when monitoring and investigating

impacts on water bodies, spatial and temporal variations for biological aspects and natural chemical processes should be considered. One of these processes is the hydrological cycle, having a direct effect on the drainage system of water bodies and causing surface runoff along the river banks.

The importance of studying seasonality is an important step towards better understanding the physicochemical and biological characteristics of a water body and is, therefore, a determining factor in hydrological changes (Peñas et al. (2016). According to Awad et al. (2017) environmental variables, such as the concentration of dissolved organic matter in a river, are directly influenced by climate change and seasonality, as well as other anthropogenic factors and peculiar natural processes. According to Álvarez-Cabria et al. (2016), some studies consider only one season (e.g. summer), missing the temporal variability of numerous water quality characteristics, which makes it difficult to understand due to the lack of spatial and seasonal information.

The chemical and Physico-chemical parameters of a water body determine its usefulness as well as the health of the ecosystem. Several investigative studies are focused on assessing the influence of chemical and physicochemical parameters on the biotic community of rivers, lakes, and dams. Cudowski et al. (2013) investigated the effects of physical and chemical water parameters on the abundance and species diversity of aquatic fungi in the Augustow canal, located in north-eastern Poland. Low and medium-depth lakes and large rivers occupy vast areas of tropical grassland, where, in these environments, the hydrological cycle of the main river is the determining factor of ecosystem function and biodiversity balance (Lobato et al. (2015)).

To assess the intensity of anthropogenic actions and the natural conditions of water resources, several methodologies are used to identify the factors and precursor mechanisms of water quality changes, such as multivariate statistical analysis and geostatistical techniques, among others (Belkhiri and Narany (2015). The use of geostatistical methods emerges as an important tool both for analysis and estimation of data and its transversality allows to be worked in different areas such as soil science, hydrology, and environmental sciences (Silva et al. (2010); Cigagna et al. (2015); Curtarelli et al. (2016). In this context, geostatistics emerges as a tool capable of estimating values of an attribute, its correlations integrating time and/or space (Koppe et al. (2006); Sibaldelli et al. (2015)).

Based on this premise, this study seeks to characterize and assess the spatial and temporal patterns of water quality in the Tucuruí Hydro-Electric Power Pool (Tucuruí Hydro-Power Complex) in Pará State, using biological and Physicochemical data and geostatistical tools as instruments.

\section{MATERIAL AND METHODS}

\subsection{STUDY AREA AND COLLECTION STATIONS}

This project was undertaken with the assistance of researchers from the Environmental and Analytical Chemistry Laboratory (LAQUANAM) of the Pará Federal University (UFPA), the Pará Federal Institute of Education, Science and Technology, the Amazonia Rural Federal University (UFRA), and the Pará Health Department Central Laboratory (LACEN-SESPA), over a total period of 24 months, in the Tucuruí Hydro-Power Complex reservoir (UHET). 
The reservoir covers an area of some $3.450 \mathrm{~km} 2$, with an accumulated drainage area of 758,000km2 influencing the Tocantins River. It is located on the Tocantins River in Pará State, some $7.5 \mathrm{~km}$ upstream from the town of Tucuruí, and $300 \mathrm{Km}$ from the city of Belém, the capital of Pará State. The Tucuruí Hydro-Power Complex has the Tocantins River as its main tributary. The Araguaia River also contributes as a tributary, although it has its basin, and this association is called the TocantinsAraguaia basin.

The collections were undertaken along the reservoir of the Tucuruí HydroPower Complex (Figure 1) at the pre-defined water intakes stations: C1 (Caraipé 1), C2 (Caraipé 2), M1 (Montante 1), M3 (Montante 3), M5 (Montante 5), MBL (Montante Belauto), MBB (Montante Breu Branco), MP (Montante Pucuruí), MR (Montante Repartimento), MI (Montante Ipixuna), MJ (Montante Jacundá Velho), ML (Montante Lontra), CF (Canal de Fuga), LT (Transmission Line), JT (Downstream Tucuruí), and NP (Nazaré dos Patos), the points were identified and geo-referenced, and the selection of stations was based on previous studies undertaken by Eletronorte, the company in charge of managing the dam. As for sampling, bimonthly sampling was chosen, to obtain statistically significant data.
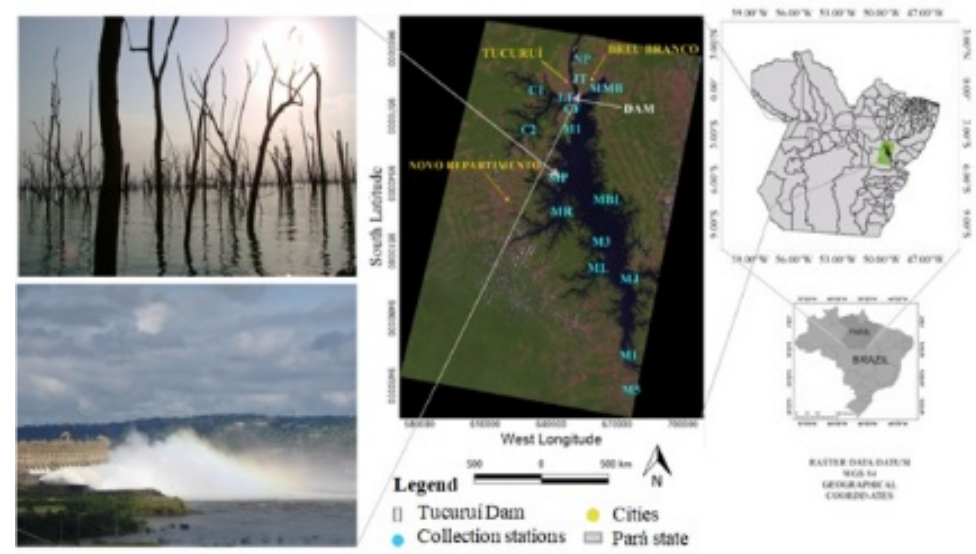

Figure 1 Map of location of the collection stations in the reservoir of Tucuruí HPP.

The parameters that will be discussed in this document were analyzed in situ, to portray the original condition of the environment. Among the parameters listed is pH, DO (dissolved oxygen), and turbidity. For determination, a HI9829 Hanna multi-parameter probe was used, previously calibrated as suggested in the manufacturer's manual. The campaigns obeyed the following conditions: winter period (March) and summer (August); two intermediate periods (June and October), respecting the peculiarities of the Amazon region. The collected material was stored in thermal containers to maintain the conservation temperature $\left(4^{\circ} \mathrm{C}\right)$, ensuring its transfer to the facilities of the Laboratory of Analytical and Environmental Chemistry of the Federal University of Pará. In the laboratory environment, complementary analyses of chlorophyll and COD (Chemical Oxygen Demand) were performed, following methodologies suggested by the reference environmental control agencies (APHA, AWWA, WEF (2012)).

\subsection{GEOSTATISTICAL MAPS}

To develop the geostatistical maps, the free program QGIS found on the website https://qgis.org/downloads/QGIS-OSGeo4W-3.10.7-1-Setup-x86_64.exe (public 
domain) and satellite image of the Tucuruí HPP reservoir area obtained from the image gallery available on the website http://www.inpe.br/ (public domain) of the National Space Research Institute website ((INPE) (2018)) were used.

The type of image used was the Landsat- 8 satellite, $0 \%$ cloud visibility OLI sensor of the dam under study. The image was converted to RGB (Red, Green, Blue) format. It was then georeferenced with the coordinates of each collection point using Qgis v.16.2 software, to be overlaid with the interpolations of each parameter. The data were subjected to the kriging interpolation method in Surfer v.13.0 software. For data interpolation, grids were generated for each parameter, where the length and latitude of each point and the data for each parameter were arranged in columns on the software worksheet in $\mathrm{x}, \mathrm{y}$, and $\mathrm{z}$, respectively.

With the grids, contour maps were generated by selecting a colour ramp indicating the concentrations, estimating the area of the intensity of local physicochemical variations, and interpolation of concentrations for unsampled areas. The penultimate step consisted of digitizing (cropping) each contour map, referencing the area that includes the entire UHET reservoir from the satellite image. The contour maps were then cut into the (blank) option and overlaid (Map Overlays) on the referenced satellite image.

\section{RESULTS AND DISCUSSION}

When evaluating the Dissolved Oxygen isotopic maps (Figure 2), the analytical information indicated oscillations along the dam with averages ranging from 7.00 in winter, $6.46 \mathrm{mg} \mathrm{L}^{-1}$ in the intermediate period I, $6.73 \mathrm{mg} \mathrm{L}^{-1}$ in summer, and $5.77 \mathrm{mg}$ $\mathrm{L}^{-1}$ in the intermediate period II.

Santos et al. (2014), evaluated the Dissolved Oxygen (D0) concentration in the Xingu River and compared it with the values obtained in the Tucuruí Hydroelectric Power Plant reservoir in 2006, showing that the average DO at Tucuruí was $6.63 \mathrm{mg}$ $\mathrm{L}^{-1}$, therefore similar to that obtained in this research. Authors such as Lobato et al. (2015); Affonso et al. (2011) also identified variations in some water quality parameters in the Tucuruí HPP reservoir, particularly the average DO content of $5.67 \mathrm{mg} \mathrm{L}^{-1}$.

Variations were identified at point (C1), present at the intermediate station II, where the low concentration of DO in the dam is expressed with the intensity of the red colour on the map.
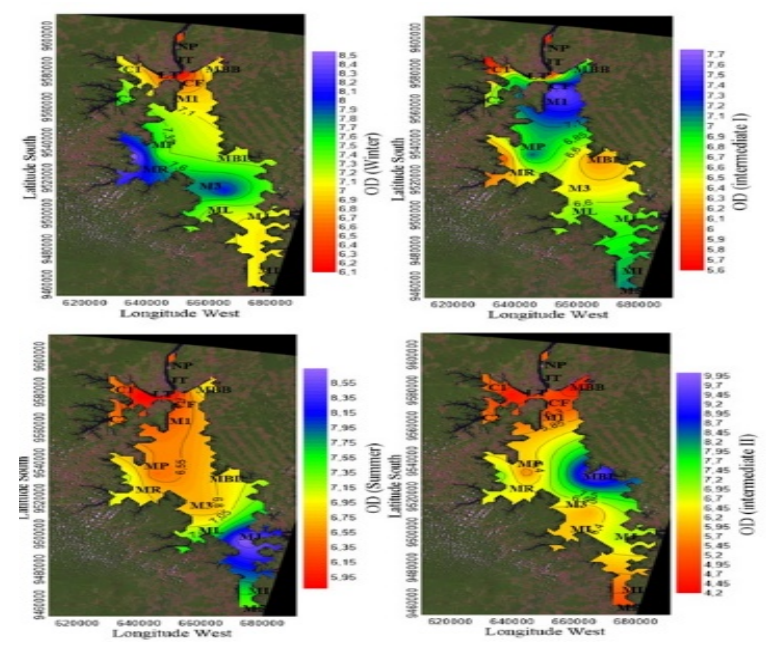

Figure 2 Space-temporal contour maps of the dissolved oxygen (DO) in the reservoir of Tucuruí HPP. 
In the analysis of interpolation maps with COD data (Figure 3), seasonality presents itself as a relevant variable for the interpretation of the distribution of COD values. In the winter period, higher concentrations were recorded at points M5 and MI, both with values of $0.55 \mathrm{mg} \mathrm{L}^{-1}$, in the south-central and southern portions of the dam. In this region, the increase may be related to natural and anthropogenic influences such as erosion, riparian forest flooding, and drainage of domestic effluents into the lake. The northwestern region of the dam, the COD concentration was stable throughout the period, ranging from $6.69 \mathrm{mg} \mathrm{L}^{-1}$ at point $\mathrm{C} 1$ to $7.18 \mathrm{mg} \mathrm{L}^{-}$ 1 at point C2. High precipitation influences the availability of organic and inorganic nutrients to the lake (Souza et al. (2021)).

In the intermediate season I (winter-summer), the COD concentrations in the southern, southeastern and eastern regions decreased compared to the winter period which recorded an average of $6.18 \mathrm{mg} \mathrm{L}^{-1}$. The increase in COD was observed in the central-western region of the dam, where the maximum value found corresponded to point MP with $8.4 \mathrm{mg} \mathrm{L}^{-1}$. The soil of this region is characterized by presenting selective agricultural and livestock capacity, with emphasis on the city of Novo Repartimento that presents itself as the largest producer of bananas in the State and the second largest cattle herd, according to the agricultural balance of 2015 (PDRS (2016)). It can also be highlighted that the city, in the year 2015 suffered the largest deforestation among the municipalities in the region, followed by Nova Ipixuna and Itupiranga that constitute the group of cities influenced by the dam. These factors exert great pressure on the local environment, contributing negatively to water quality.

In the summer, due to the lower amount of rainfall in the region, the concentration of organic matter in a large part of the dam was reduced. Some regions, however, showed an increase in concentration, such as the southeastern portion, which is affected by the city of Jacundá, with the highest COD at point MJ of $9.63 \mathrm{mg} \mathrm{L}^{-1}$, and the edge of the dam in the central-eastern region, represented by point MBL, which showed a COD of $8.65 \mathrm{mg} \mathrm{L}^{-1}$, as illustrated in the contour maps. The low COD content for the period, was observed in the northwestern region, where points $\mathrm{C} 1$ and $\mathrm{C} 2$ are located (5.63 mg L-1 and $5.06 \mathrm{mg} \mathrm{L}^{-1}$ respectively), the center-south to the west, represented by point ML, with a value of $6.2 \mathrm{mg} \mathrm{L}^{-1}$, and the southern region of the dam with values of $\mathrm{mg} \mathrm{L}^{-1}$ in MI and $5.06 \mathrm{mg} \mathrm{L}^{-1}$ in M5. In addition, the NP point downstream of the dam showed low COD of $4.9 \mathrm{mg} \mathrm{L}^{-1}$.

The behaviour of the physical and chemical variables at the dam with different values for COD and the other parameters evaluated is due mainly to the construction of the Tucuruí Hydro-Power Complex, which caused spatial heterogeneity in this region, resulting in consequences such as the transport of pollutants (Espíndola et al. (2000); Cardoso et al. (2018). Land use and occupation for anthropogenic activities intensify alterations in water quality (Catherine et al. (2013)). In the intermediate period II (Summer-Winter), a COD behaviour like that of summer was observed, except in the northwestern and central-eastern regions, which the decrease was reduced compared to that obtained in summer. As observed in the previous period, the highest value was in the southeast region at point MJ, with 7.84 $\mathrm{mg} \mathrm{L}^{-1}$, and the lowest COD at point JT, with $3.36 \mathrm{mg} \mathrm{L}^{-1}$. 

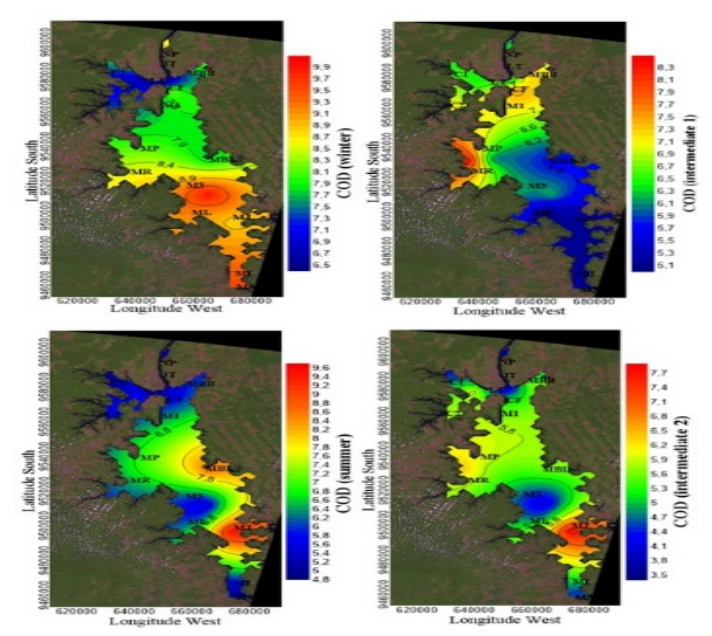

Figure 3 Space-temporal contour maps of the chemical oxygen demand (COD) in the reservoir of Tucuruí HPP.

Regarding pH (Figure 4), variations were identified in all periods, in the four seasons, showing variability in relation to seasonality. The lowest values were observed in the winter and summer seasons. Lobato et al. (2015) and Mulling et al. (2013), evaluated physicochemical parameters in the Tucuruí UHE reservoir for the categorization of the trophic state and identified $\mathrm{pH}$ indices during the variation of the hydrological cycle and $6.94 \leq \mathrm{pH} \leq 7.28$, with an average of approximately 7.109 at the surface, similar to that found in this research (6.99) at the surface.

In continental waters such as the UHET, pH values ranged between 6.0 and 9.0. However, it is possible to find regions with more acidic or slightly alkaline $\mathrm{pH}$, where organic nutrient availability, water retention time, and pressures caused by anthropogenic activities may vary in intensity between regions (Tubenchlak et al. (2021); IANAS (2019)).

Slightly alkaline $\mathrm{pH}$ was observed upstream of the dam, which runs from the southwestern portion, which is the location of point ML, extending to the northern region consisting of the dam and the towns of Breu Branco and Tucuruí. The catchment area of points $\mathrm{C} 1, \mathrm{C} 2, \mathrm{MBB}$, and M1 is characterised by a water column with longer retention times, vertical stratification and an anoxic apical zone during the summer period, as can be seen on the maps. Despite the pressure of the intense flux of populations of different species, high temperatures, local geochemical characteristics, and other factors, a low $\mathrm{pH}$ is expected. One justification for the less acidic condition in the mentioned regions, may be related to the reduced buffer capacity of some water bodies. Water bodies with low $\mathrm{pH}$ values typically maintain the presence of bicarbonate and carbonate compounds (Freire et al. (2017); Piratoba et al. (2017).

In the southern and southeastern part of the same station, the acidic character of the water for this region may be related to anthropogenic influences from the city of Itupiranga and natural processes such as diffusion of carbon dioxide $\left(\mathrm{CO}_{2}\right)$ into the water from the air, photosynthesis, and oxidation of submerged organic matter, producing humic and fulvic acids as by-products. In summer it showed low pHs in the north and northwest, which are located at points C1, C2 M1, and CF. Due to the longer retention time of the water column in the northwest ( $\mathrm{C} 1$ and $\mathrm{C} 2$ ) and other parts of the dam, the high incidence of sunlight favours changes in the $\mathrm{pH}$ of the medium, increasing the speed of oxidation of nutrients by microbial and photochemical degradation, organic matter being the main reductant in natural 
aqueous environments, thus making the water acidic (Santos et al. (2018); Neuman (2012).
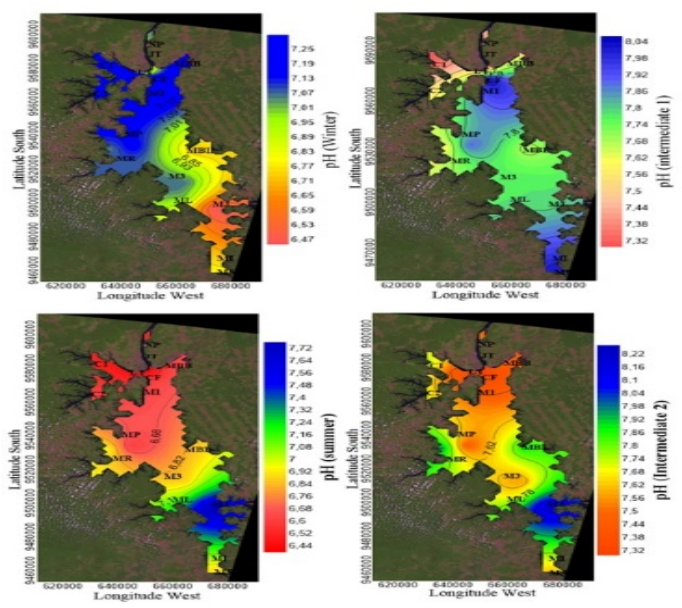

Figure 4 Space-temporal contour map of the hydrogenation potential $(\mathrm{pH})$ in the reservoir of Tucuruí HPP.

The isoteor maps illustrate that Chlorophyll-a concentrations in the winter period (Figure 5) were higher in the vicinity of the town of Novo Repartimento. In

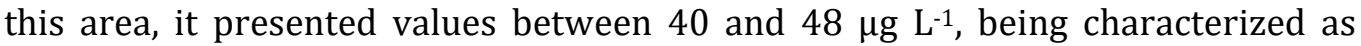
ultraoligotrophic state, as per standard established by CETESB in 2019.

For the intermediate period I (Winter-Summer), the situation reverses, with higher concentrations in the middle of the dam and near the town of Itupanema. It is noted that the maximum found for this period is $7.0 \mu \mathrm{g} \mathrm{L} \mathrm{L}^{-1}$. The explanation for concentration reversal from one period to the next requires further investigation, which should take into account factors such as precipitation, flow, depth, lighting, among others.

In the summer and intermediate II periods, there was no significant inversion as occurred previously. The highest concentrations were found in the vicinity of point MJ. At this point, the environment is lentic in this period, which may provide conditions for the concentration of Chlorophyll-a to be high. The concentrations at both stations exceed $50 \mu \mathrm{g} \mathrm{L} \mathrm{L}^{-1}$, characterizing an oligotrophic condition (Lam et al. (2020).
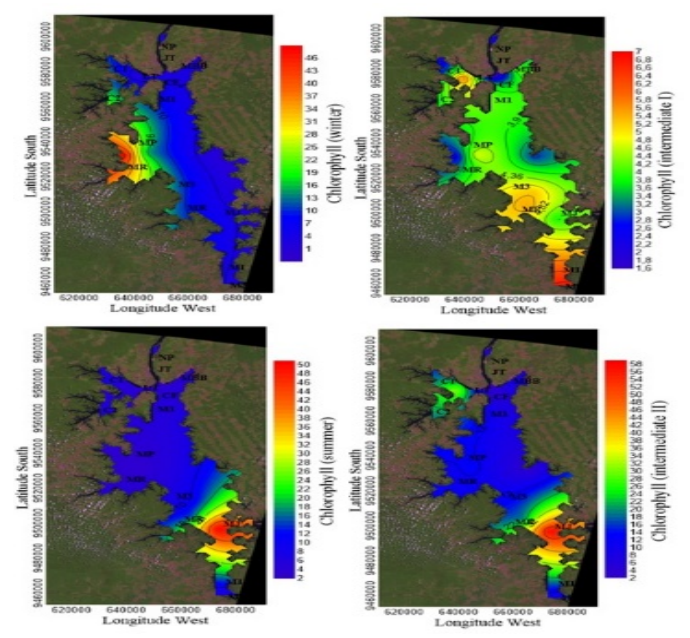

Figure 5 Space-temporal contour map of the chlorophyll-a in the reservoir of Tucuruí . 
The results of turbidity in the studied area revealed that the highest values were found in winter, especially in the central-western region, through points MP, MI, and ML, which presented 65.0, 38.3 and 26.7 UNT respectively, and point M5 with 27.7 UNT, located south of the dam, as shown in Figure 6.

It is assumed that due to the higher precipitation in the period, this fact favors surface runoff and leaching, transporting organic matter and other chemicals from pesticides and other agro-industrial activities, altering the water characteristics ( $\mathrm{Li}$ et al. (2011).

In the intermediate period I, turbidity at points M5, MR, and MI presented values of $12.9,8.84$, and 6.61 UNT, respectively. Due to the size and complexity of the Tucuruí Hydro-Power Complex. Cintra et al. (2013) states that rainfall does not occur uniformly in this region, and this factor causes different conditions in the same area. Furthermore, there are regions with greater vegetation cover which therefore prevents greater surface soil runoff.
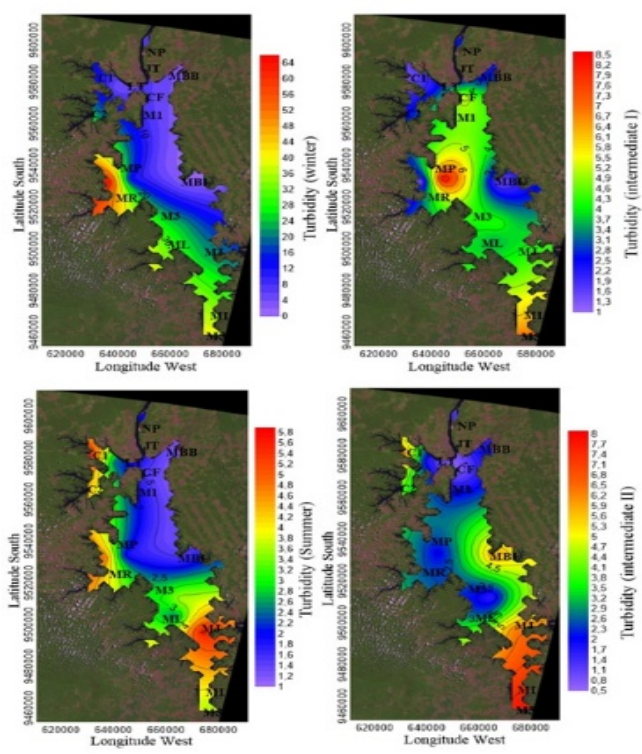

Figure 6 Space-temporal contour map of the tubidity in the reservoir of Tucuruí HPP.

\section{CONCLUSION}

This study revealed that the seasonal variations in the Tucuruí Hydro-Power Complex reservoir contribute considerably to the parameters analysed, and consequently to the quality of the water. In this study, it was found that some parameters (DO and Chlorophyll-a) showed concentrations outside the CONAMA Resolution 357/2005 standards during the intermediate period II.

The behavior in the spatial-temporal distribution of the results obtained from each parameter evaluated was expressed through isothermal contour maps. The use of geostatistical maps proved valuable in providing a broader view of the studied environment and its environmental conditions supported by analytical results of chemical order. The use of geotechnologies provides important assessments in highly complex environmental research, aiding in interpreting the results, reducing the logistical costs of field analysis, and supporting monitoring and planning in decision-making and research. 


\section{ACKNOWLEDGEMENT}

Our sincere thanks to the sponsorship of the Agência Nacional de Energia Elétrica (ANEEL), Brazil, and the laboratory support of Eletronorte - Tucuruí.

\section{REFERENCES}

Affonso AG, Barbosa C, Novo EMLM (2011). Water quality changes in floodplain lakes due to the Amazon River flood pulse: Lago Grande de Curuaí (Pará). Braz. J. Biol., 71(3), 601-610. doi: https://doi.org/10.1590/S151969842011000400004. Retrieved from https://doi.org/10.1590/S151969842011000400004

Álvarez-Cabria M, Barquín J, Peñas FJ (2016). Modelling the spatial and seasonal variability of water quality for entire river networks: Relationships with natural and anthropogenic factors. Science of The Total Environment 545, 152-162. doi:10.1016/j.scitotenv.2015.12.109. Retrieved from https://doi.org/10.1016/j.scitotenv.2015.12.109

APHA, AWWA, WEF (2012) Standard Methods for examination of water and wastewater. 22nd ed. Washington: American Public Health Association; 1360 pp. ISBN 978-087553-013-0

Awad J, Van Leeuwen J, Chow CWK, Smernik RJ, Anderson SJ, Cox JW (2017). Seasonal variation in the nature of DOM in a river and drinking water reservoir of a closed catchment. Environmental Pollution 220, 788-796. doi:10.1016/j.envpol.2016.10.054. Retrieved from https://doi.org/10.1016/j.envpol.2016.10.054

Belkhiri L, Narany TS (2015). Using multivariate statistical analysis, geostatistical techniques and structural equation modeling to identify spatial variability of groundwater quality. Water Resources Management 29, 2073-2089. doi:10.1007/s11269-015-0929-7. Retrieved from https://doi.org/10.1007/s11269-015-0929-7

COMPANHIA AMBIENTAL DO ESTADO DE SÃO PAULO (CETESB). Índices dequalidade das águas. São Paulo: CETESB, 2019. Disponível em: http://www.cetesb.sp.gov.br/agua/\%C3\%A1guas-superficiais/108\%C3\%ADndices-de-qualidade-das-\%C3\%A1guas> Acesso em: 18 Jun. 2019.

Cardoso CMM, Cardoso NCVFM, Mendonça ARV, Pedroza MM, Vieira GEG, Oliveira JD (2018) Quantificação da matéria orgânica em rios da Amazônia brasileira sob a influência de resíduos da indústria de curtume. Revista AIDIS de Ingeniería y Ciencias Ambientales: Investigación, desarrollo y práctica 11 (2), 153-166. doi: Retrieved from http://dx.doi.org/10.22201/iingen.0718378xe.2018.11.2.58365.

Catherine A, Mouillot D, Maloufi S, Troussellier M, Bernard C (2013). Projecting the Impact of Regional Land-Use Change and Water Management Policies on Lake Water Quality: An Application to Periurban Lakes and Reservoirs. PLoS ONE 8, e72227. doi:10.1371/journal.pone.0072227. Retrieved from https://doi.org/10.1371/journal.pone.0072227

Cigagna C, Bonotto DM, Sturaro JR, Camargo AFM (2015). Geostatistical techniques applied to mapping limnological variables and quantify the uncertainty associated with estimates. Acta Limnologica Brasiliensia 27, 421-430. doi:10.1590/S2179-975X3315.

Retrieved from 
Cintra IHA, Flexa CE, Silva MB, Araújo MVLF, Silva KCA (2013). Fishing in reservoir of the Tucuruí hydroelectric power station, Amazon region, Brazil: biological aspects, social, economic and environmental. Acta of Fisheries and Aquatic Resources 1, 57-78. doi:10.2312/ActaFish.2013.1.1.57-78.

Cudowski A, Pietryczuka A, Hauschild T (2013). Aquatic fungi in relation to the physical and chemical parameters of water quality in the Augustów Canal. Fungal ecology 13, 193-204. doi:10.1016/j.funeco.2014.10.002. Retrieved from https://doi.org/10.1016/j.funeco.2014.10.002

Curtarelli MP, Ogashawara I, Araújo CAS, Lorenzzetti JA, Leão JAD, Alcântara E, Stech JL (2016). Carbon dioxide emissions from Tucuruí reservoir (Amazon biome): New findings based on three-dimensional ecological model simulations. Science of the Total Environment 551-552, 676-694. doi:10.1016/j.scitotenv.2016.02.001. Retrieved from https://doi.org/10.1016/j.scitotenv.2016.02.001

Di Blasi JIP, Torres JM, Nieto PJG, Fernández JRA, Muñiz C D, Tadaboa J (2013). Analysis and detection of outliers in water quality parameters from different automated monitoring stations in the Miño river basin (NW Spain). Ecological Engineering 60, 60-66. doi:10.1016/j.ecoleng.2013.07.054. Retrieved from https://doi.org/10.1016/j.ecoleng.2013.07.054

Döll P, Fiedler K, Zhang J (2009). Global-scale analysis of river flow alterations due to water withdrawals and reservoirs. Hydrol. Earth Syst. Sci. 13, 2413-2432. doi:10.5194/hess-13-2413-2009. Retrieved from https://doi.org/10.5194/hess-13-2413-2009

Espíndola ELG, Matsumura-Tundisi T, Rietzler AC, Tundisi JG (2000). Spatial heterogeneity of the Tucuruí Reservoir (State of Pará, Amazonia, Brazil) and the distribution of zooplanktonic species. Revista Brasileira de Biologia 60, 170-194. doi:10.1590/S0034-71082000000200001. Retrieved from https://doi.org/10.1590/S0034-71082000000200001

Freire JCA, Hauser Davis RA, Lobato TC, Jefferson M. de, Morais TFO, Saraiva ACF (2017) Influence of the Amazon hydrological regime on eutrophication indicators of a hydroelectric power plant reservoir. Bull Environ Contam Toxicol 98, 677-681 doi: 10.1007/s00128-017-2030-9. Retrieved from https://doi.org/10.1007/s00128-017-2030-9

IANAS - Inter-American Network of Academies of Sciences (2019). Water Quality in the Americas Risks and Opportunities. IANAS-IAP, UNESCO and CODIA 626pp. Available from: Retrieved from https://www.interacademies.org/sites/default/files/publication/water_q uality_in_the_americas.pdf.

Instituto Nacional de Pesquisas Espaciais (INPE) (2018). Catálogo de Imagens. Available from: Retrieved from http://www.dgi.inpe.br.

Kazi TG, Arain MB, Jamali M K, Jalbani N, Afridi H I, Sarfraz RA, Baig JA, Abdul QS (2009). Assessment of water quality of polluted lake using multivariate statistical techniques: A case study. Ecotoxicology and Environmental Safety 72, 301-309. doi:10.1016/j.ecoenv.2008.02.024. Retrieved from https://doi.org/10.1016/j.ecoenv.2008.02.024

Koppe VC, Costa JFCL, Koppe JC (2006). Coordenadas cartesianas x coordenadas geológicas em geoestatística: Aplicação à variável vagarosidade obtida por perfilagem acústica. REM: R. Esc. Minas 59, 25-30. doi:10.1590/S037044672006000100004. Retrieved from https://doi.org/10.1590/S037044672006000100004 
Lam KL, Zlatanovic L, Van Der Hoek JP (2020). Life cycle assessment of nutrient recycling from wastewater: A critical review. Water Research 173, 115519(1-16). doi:10.1016/j.watres.2020.115519. Retrieved from https://doi.org/10.1016/j.watres.2020.115519

Li W, Zhang P, Ye J, Li L, Baker PA (2011). Impact of two different types of El Niño events on the Amazon climate and ecosystem productivity. J. Plant Ecol. 4 (1-2), 91-99. doi: 10.1093/jpe/rtq039. Retrieved from https://doi.org/10.1093/jpe/rtq039

Lobato TC, Hauser-davis RA, Oliveira, TF, Silveira AM, Silva HAN, Tavares MRM, Saraiva ACF (2015). Construction of a novel water quality index and quality indicator for reservoir water quality evaluation: A case study in the Amazon region. J. Hydrol. (Amsterdam, Neth.) 522, 674-683. doi:10.1016/j.jhydrol.2015.01.021. Retrieved from https://doi.org/10.1016/j.jhydrol.2015.01.021

Moreira, PF (2012). O Setor Elétrico Brasileiro e a Sustentabilidade no Século 21: Oportunidade e Desafios (2ª ed.). Brasília, DF, Brazil: Rios Internacionais, 19 pp.

Mulling BTM, Van Den Boomenb RM, Claassen THL, Van Der Geest HG, Kappelhof JWNM, Admiraal W (2013). Physical and biological changes of suspended particles in a free surface flow constructed wetland. Ecological Engineering 60, 10-18. doi:10.1016/j.ecoleng.2013.07.017 Retrieved from https://doi.org/10.1016/j.ecoleng.2013.07.017

Neuman T (2012). Fundamentals of aquatic chemistry relevant to radionuclide behaviour in the environment. In: Poinssot, C.; Geckeis, H. (Ed.) Radionuclide behaviour in the natural environment: Science, implications and lessons for the nuclear industry. (Cambridge: Woodhead Publishing).

PDRS (2016). Plano de desenvolvimento regional sustentável do lago de Tucuruí. Governo do estado do Pará. Available from: Retrieved from http://www.mme.gov.br.

Peñas FJ, Barquín J, Álvarez C (2016). Assessing hydrologic alteration: Evaluation of different alternatives according to data availability. Ecological Indicators 60, 470-482. doi:10.1016/j.ecolind.2015.07.021. Retrieved from https://doi.org/10.1016/j.ecolind.2015.07.021

Piratoba ARA, Ribeiro HMC, Morales GP, Gonçalves WG (2017). Caracterização de parâmetros de qualidade da água na área portuária de Barcarena, PA. Revista Ambiente e Água 12, 435-456. doi:10.4136/ambi-agua.1910. Retrieved from https://doi.org/10.4136/ambi-agua.1910

Poff NL, Olden JD, Merritt DM, Pepin DM (2007). Homogenization of regional river dynamics by dams and global biodiversity implications. Proc. Natl. Acad. Sci. 104, 5732-5737. doi:10.1073/pnas.0609812104. Retrieved from https://doi.org/10.1073/pnas.0609812104

Santos ES, Lopes PPP, Pereira HHS, Nascimento OO, Rennie CD, Sternberg LSLO'R, Cunha AC (2018). The impact of channel capture on estuarine hydromorphodynamics and water quality in the Amazon delta. Science of the Total Environment 624, 887-899. doi:10.1016/j.scitotenv.2017.12.211. Retrieved from https://doi.org/10.1016/j.scitotenv.2017.12.211

Santos KCF, Mitschein TA, Pereira SFP, Nogueira, DP, Silva CS (2014) Impacto ambiental da construção da UHE Belo Monte sobre a qualidade da agua do rio Xingu. Proceedings of International Conference on Engineering and Technology

Education

13 , 407-411. doi: 
10.14684/INTERTECH.13.2014.407-411.

Retrieved

from https://doi.org/10.14684/intertech.13.2014.411-415

Souza AMF, Pereira SFP, Santos LP, Silva CS, Rocha RM, Sousa RM, Nogueira DP (2021) Software for calculating a water quality indicator specific to the Amazon region. International Journal of Research-Granthaalayah 9(3), 248261. doi:10.29121/granthaalayah.v9.i3.2021.3802. Retrieved from https://doi.org/10.29121/granthaalayah.v9.i3.2021.3802

Sibaldelli RNR, Carvalho JFC, Oliveira MCN (2015). Uso de Geoestatística no Estudo da Variabilidade Espacial da Capacidade de Troca de Cátions do Solo. Gl. Sci Technol, 8, 141-156. doi: 10.14688/1984-3801/gst.v8n1p141-156 Retrieved from https://doi.org/10.14688/1984-3801/gst.v8n1p141-156

Silva SA, Lima JSS, Souza GS (2010). Estudo da fertilidade de um latossolo vermelhoamarelo húmico sob cultivo de café arábica por meio de geoestatística. Rev. Ceres 57, 560-567. doi:10.1590/S0034-737X2010000400020. Retrieved from https://doi.org/10.1590/S0034-737X2010000400020

Tubenchlak F, Badari CG, Freitas SG, Moraes LFD (2021). Changing the Agriculture Paradigm in the Brazilian Atlantic Forest: The Importance of Agroforestry. In: Marques M.C.M., Grelle C.E.V. (eds) The Atlantic Forest. Springer, Cham. doi: 10.1007/978-3-030-55322-7_17. Retrieved from https://doi.org/10.1007/978-3-030-55322-7_17 